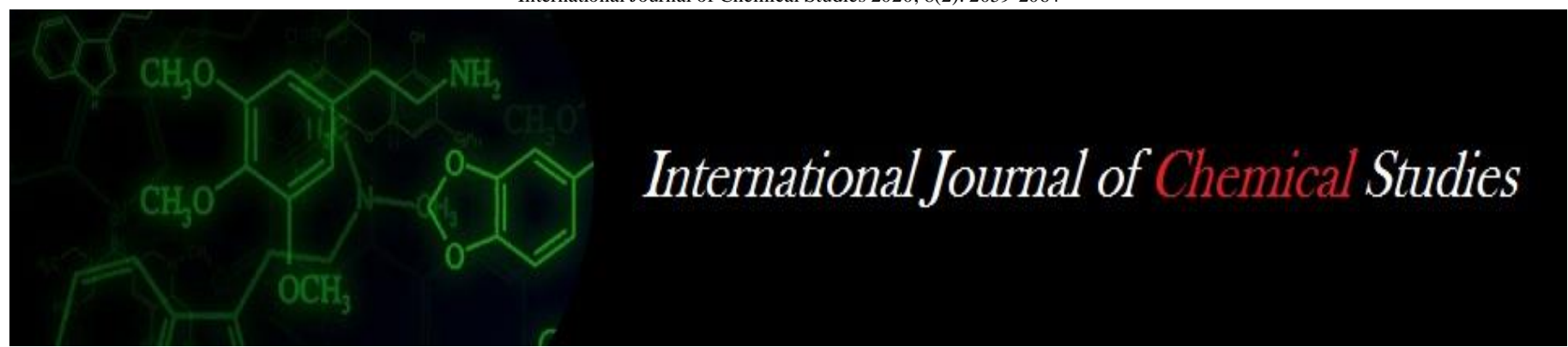

P-ISSN: 2349-8528

E-ISSN: 2321-4902

www.chemijournal.com

IJCS 2020; 8(2): 2059-2064

(C) 2020 IJCS

Received: 16-01-2020

Accepted: 18-02-2020

Pallavi Srivastava

Department of Plant Physiology,

Institute of Agricultural

Sciences, Banaras Hindu

University, Varanasi, Uttar

Pradesh, India

Pravin Prakash

Department of Plant Physiology,

Institute of Agricultural

Sciences, Banaras Hindu

University, Varanasi, Uttar

Pradesh, India

Durga Shankar Bunkar

Department of Dairy Science and

Food Technology, Institute of

Agricultural Sciences, Banaras

Hindu University, Varanasi,

Uttar Pradesh, India
Corresponding Author: Pallavi Srivastava

Department of Plant Physiology,

Institute of Agricultural

Sciences, Banaras Hindu

University, Varanasi, Uttar

Pradesh, India

\section{Enhancement in physiological and sensory attributes of button mushroom (Agaricus bisporus) as influenced by chemical and modified atmospheric packaging (MAP) treatments at low temperature storage}

\author{
Pallavi Srivastava, Pravin Prakash and Durga Shankar Bunkar
}

DOI: https://doi.org/10.22271/chemi.2020.v8.i2ae.9058

\begin{abstract}
This study investigated the effects of modified atmosphere packaging (MAP) with different chemical treatments on the storage life and fruit quality of button mushroom. Agaricus bisporus fruiting bodies were chemically treated with $\mathrm{CaCl}_{2}(2.5 \% \mathrm{w} / \mathrm{v})$, citric acid $(3 \% \mathrm{w} / \mathrm{v})$ and sorbitol $(0.1 \% \mathrm{w} / \mathrm{v})$, then packed under three MAP air composition (MAPI: $6 \% \mathrm{O}_{2}, 12 \% \mathrm{CO}_{2}$; MAPII: $12 \% \mathrm{O}_{2}, 6 \% \mathrm{CO}_{2}$; MAPIII: $20.95 \% \mathrm{O}_{2}, 0.04 \% \mathrm{CO}_{2}$ ). After modified atmosphere packaging, the samples were stored at $8^{\circ} \mathrm{C}$ for 16 days and different observations were recorded at interval of 4 days. Button mushroom which were chemically treated followed by modified atmosphere packaging with air composition $6 \% \mathrm{O}_{2}$ and $12 \% \mathrm{CO}_{2}$ showed better water retention qualities, higher sensory ratings which lead to storage life of about 16 days. Samples with this air composition have very less changes in TSS, $\mathrm{pH}$, browning index and electrolyte leakage rate. Samples without chemical treatments and higher oxygen concentration undergo very fast degradation and spoiled after 16 days.
\end{abstract}

Keywords: Modified atmosphere packaging, $\mathrm{CaCl}_{2}$, sorbitol, button mushroom

\section{Introduction}

Worldwide, demand for fresh, healthy and delicious food is continuously increasing as there is shift in people's lifestyle and due to breakthrough of retail marketing. Button mushroom is such food product which accomplishes all demands of the community. But due to very short shelf-life button mushroom cannot be stored too long and also faces trouble in its transportation. So, adoption of new technologies can boost its shelf life (Belay et al., 2016) ${ }^{[4]}$. A number of experimental researches have been conducted for improving shelf life of mushrooms including modified atmosphere packaging and different chemical treatments. Modified atmosphere packaging mainly relies on changing gas composition which surrounds the edible food products depending upon packaging material thickness, its $\mathrm{CO}_{2}$ and $\mathrm{O}_{2}$ permeability and respiration rate of stored food products ( $\mathrm{Li} \&$ Ishikawa, 2014) ${ }^{[16]}$. It was reported that overwrapping the mushrooms by polyvinyl chloride film also enhances shelf life of button mushroom (Licciardello et al., 2018) ${ }^{[14]}$. It was reported by Roy et al. (1995) ${ }^{[23]}$ that $6 \% \mathrm{O}_{2}$ is the perfect oxygen concentration that can be used for packaging of button mushroom. Low oxygen concentration can effectively reduce cap development, aerobic respiration rates and enzymatic browning. In low concentration of oxygen, tyrosinase activity can be reduced which further decreases browning of button mushroom.

Different chemical treatments can effectively help in decreasing senescence of button mushroom when used with an appropriate gas composition packaging. Citric acid which is regularly used in chemical treatments reduces $\mathrm{pH}$ of the button mushroom, act as chelating agent and also increases the activity of the antioxidants (Brennan et al., 2000) ${ }^{[5]}$. Sorbitol is the chemical which is used in enhancing post-harvest life of the food products. Sorbitol act as water holding agent and maintain the firmness of the button mushroom (Anantheswaran et al. 1996) ${ }^{[1]}$. Chemicals like potassium metasulphite (KMS), citric acid, calcium chloride and sodium EDTA (Ethylene diamine tetra acetic acid) are used as ash guard and pays very 
important role in long term preservation of food products. Sodium EDTA, citric acid, sorbitol and calcium chloride were used by Khan et al. (2014) ${ }^{[11]}$ for improving shelf life of button mushroom. Jafri et al. (2013) ${ }^{\text {[9] }}$ used sorbitol, citric acid and calcium chloride as chemical treatments for enhancing shelf life of mushrooms.

\section{Materials and methods}

Button mushroom (Agaricusbisporus) were grown in Department of Mycology and Plant Pathology, Institute of Agricultural Sciences, Banaras Hindu University, Varanasi and were harvestedin the morning hours when their caps measured 3.0 to $4.0 \mathrm{~cm}$ in diameter. Button mushrooms which were free from any physical injury were selected for the experiment purpose. Fresh button mushroom were washed properly and then air died on the filter paper followed by different chemical and MAP treatments provided at the Centre of Food Science and Technology, Institute of Agricultural Sciences, Banaras Hindu University, Varanasi.

\section{Methodology}

Fresh button mushroom free from injury were selected after washing and drying and followed by different chemical treatments. The three chemical treatments were $2.5 \% \mathrm{CaCl}_{2}$, $2.5 \% \mathrm{CaCl}_{2}+3 \%$ citric acid $+0.1 \%$ sorbitol and Hot water treatment (blanched at $50^{\circ} \mathrm{C}$ ). Thebutton mushrooms were dipped in chemicals for 20 minutes followed by packaging of mushroom. After different chemical treatments button mushrooms were packed in polyethylene packets of polyamide $20 \mu \mathrm{m}$-polyethylene $70 \mu \mathrm{m}$ with EVA (Ethylenevinyl acetate sealant layer). Sample size of button mushroom taken was $40 \mathrm{~g}$. Packaging of mushrooms was done by modified atmosphere packaging (MAP) unit. The three MAP treatments taken were $\mathrm{MAP}_{1}\left(12 \% \mathrm{CO}_{2} ; 6 \% \mathrm{O}_{2}\right), \mathrm{MAP}_{2}(6 \%$ $\mathrm{CO}_{2} ; 12 \% \mathrm{O}_{2}$ ) and $\mathrm{MAP}_{3}$ (control, normal air composition). The button mushroom after chemical and MAP treatments were stored at $8^{\circ} \mathrm{C}$ temperature. All the observations i.e. biochemical and textural were recorded at interval of 4 days and carried out upto16 days.

\section{Head space gas analysis}

Head space gas analysis was done for $\mathrm{CO}_{2}(\%)$ and $\mathrm{O}_{2}(\%)$ in samples. The head space gas composition of samples was measured by gas analyzer (MAP Mix 9001 ME, PBI Dansensor, Ringsted, Denmark). For measuring the air composition, a needle was inserted in samples of button mushrooms through septum to ensure hole remained closed and gas concentration were expressed in percentage.

\section{pH of Agaricus bisporus}

Fresh fruiting bodies of button mushroom (10g) were homogenized in a mixer grinder followed by centrifugation process for $20 \mathrm{~min}$ at $5000 \mathrm{rpm}$. The supernatant of the centrifuge tube was collected. The $\mathrm{pH}$ of button mushroom was determined from centrifuged extract by using digital $\mathrm{pH}$ meter (Labtronics).

\section{Total soluble solids}

Centrifuged extracts of button mushroom fruiting bodies were analysed for total soluble solids with the help of refractrometer (Model RFM 970, Bellingham and Stanley, UK) (Eissa, 2008) ${ }^{[7]}$.

\section{Relative electrolyte leakage}

With the help of electrolyte leakage we can assess cell membrane permeability (Kaya et al., 2002) ${ }^{[10]}$. Fruiting bodies of button mushroom were sliced into discs of $3 \mathrm{~mm}$ thick, $3 \mathrm{~mm}$ diameter and of around 5 grams. These discs were then immersed in $50 \mathrm{ml}$ of distilled water for 1 hour for removing all the dirt and surface contamination. Then they were removed and further immersed in $50 \mathrm{ml}$ distilled water and followed by incubation at ambient temperature of $20 \pm$ $3^{\circ} \mathrm{C}$. Electrolyte conductivity was measured after 3 hour and after boiling for 30 minutes with the help of conductivity meter (DDB-303A, Leici Instrument Co., Shanghai, China). Electrolyte leakage percentage was calculated by multiplying ratio of electrolyte leakage at 3 hours to the total value by 100.

\section{Weight loss}

Weight loss of button mushroom was calculated by subtracting weight of mushrooms after storage from initial weight of the button mushroom (Singh et al., 2016) ${ }^{[26]}$. The weight loss was expressed as percentage loss in weight and it is given by:

Weight loss $(\%)=\underline{\text { Initial weight of sample }- \text { Final weight of sample }} X 100$ Initial weight of sample

\section{Instrumentation colour and browning index}

Colour of the product is the very important parameter for deciding its market value and consumer acceptance. Whenever an object is visualized there are three physical factors i.e. source of light, the object and the light receptor mechanism (Kortei et al., 2015) ${ }^{[12]}$. Instrumentally colour of the products is measured by the Hunterlab Colorimeter (Hunterslab Technical Manual, 2008) [8]. The colorimeter generates three parameters i.e. $L^{*}, a^{*}$ and $b^{*}$. In Hunterlab colorimeter these are three colour coordinates. $\mathrm{L}^{*}$ denotes the lightness coordinate, $\mathrm{a}^{*}$ denotes the red/green coordinate in which $+a^{*}$ indicates red colour and $-a^{*}$ indictes green coordinate. In case of $\mathrm{b}^{*}$ which indicates yellow/blue coordinates $+b^{*}$ indicates yellow coordinate and $-b^{*}$ indicates blue coordinates. The $\mathrm{L}^{*}, \mathrm{a}^{*}$, and $\mathrm{b}^{*}$ coordinate axis confirms the three-dimensional colour space. If the value of the $\mathrm{L}^{*}, \mathrm{a}^{*}$, and $b^{*}$ are known to us then we can easily describe colour of the product as well as its quadrant (Schnell et al., 2005) ${ }^{[25]}$. The colour of the button mushroom was measured at 0 day and after storage period of 4 days. The colorimeter has a beam diameter of $8 \mathrm{~mm}$ and the responses detectors were set at 0 viewing angle. The colorimeter was calibrated with reference white porcelain tile $\left(L_{0}=96.6, a_{0}=.48\right.$ and $\left.b_{0}=5.3\right)$ before placing samples. The value of lightness coordinate $\left(\mathrm{L}^{*}\right)$ ranges from 0 (black) to 100 (white), $a^{*}$ ranges from +60 (red) to -60 (green) and $b^{*}$ ranges from +60 (yellow) to -60 (blue) were measured in triplets. Chroma (C) is the parameter which denotes colour saturation and hue angle $\left(\mathrm{H}_{\mathrm{o}}\right)$ denotes relative amount of redness and yellowness where $0{ }^{\circ} / 360^{\circ}$ is defined for $\mathrm{red} / \mathrm{magenta}, 90^{\circ}$ denotes yellow, $180^{\circ}$ for green and $270^{\circ}$ for blue or purple colour.

Browning index (BI) represents the purity of brown colour. Browning index is considered as an important parameter related to browning of the product (Lopez-Malo et al., 1998) [17]. The browning index can be calculated by formula (Mohammadi et al., 2008) ${ }^{[20]}$ : Browning Index (B.I) $=[100$ $(\mathrm{x}-0.31)] / 0.17$, where $\mathrm{x}=\left(\mathrm{a}^{*}+1.75 \mathrm{~L}^{*}\right) /\left(5.645 \mathrm{~L}^{*}+\mathrm{a}^{*}-\right.$ $\left.3.012 b^{*}\right)$ 


\section{Statistical Design}

All the experiments were completed in triplicates and data were analysed to two-way ANNOVA which considers MAP and chemical treatments.

\section{Results and discussion}

\section{Head space gas composition}

Decreasing trends in $\mathrm{O}_{2}$ concentration and increasing trends in $\mathrm{CO}_{2}$ concentration were observed during storage period of button mushroom (Ares et al., 2006; Antmann et al., 2008) ${ }^{\text {[3, }}$ 2]. After 4 days $\mathrm{O}_{2}$ concentration was around $15 \%$ in chemically treated samples and $12 \%$ in blanched samples, which clearly indicates faster respiration rates in case of blanched samples (Fig 1). After 12 days, $\mathrm{O}_{2}$ concentration was recorded negligible in MAP packed samples and below $3 \%$ in normal air packed samples. There is considerable rise in $\mathrm{CO}_{2}$ concentration in all the samples which indicates sharp rise in respiration rates (Fig 2). Oxygen permeability rate of polyethylene film $\left(50 \mathrm{~cm}^{3} / \mathrm{m}^{2}\right.$.day.bar) prevented the complete depletion of oxygen from the packed samples. Drastic changes in atmosphere around button mushrooms were primarily due to consumption of $\mathrm{O}_{2}$ and production of $\mathrm{CO}_{2}$ as by-product of respiration which were much higher than permeability rates of packaging film (Jafri et al., 2013) ${ }^{[9]}$.

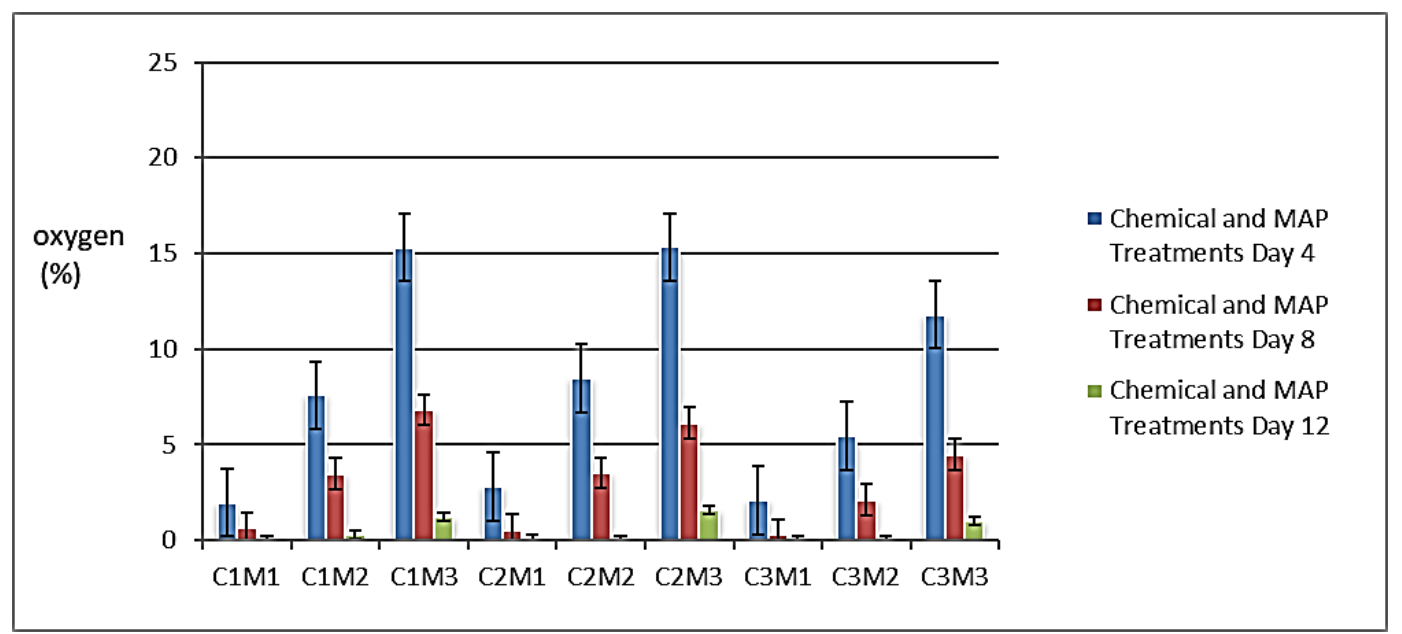

Fig 1: Effect of different chemical and MAP treatments on head space gas composition (percentage oxygen concentration) of button mushroom (Agaricusbisporus) at $8^{\circ} \mathrm{C}$

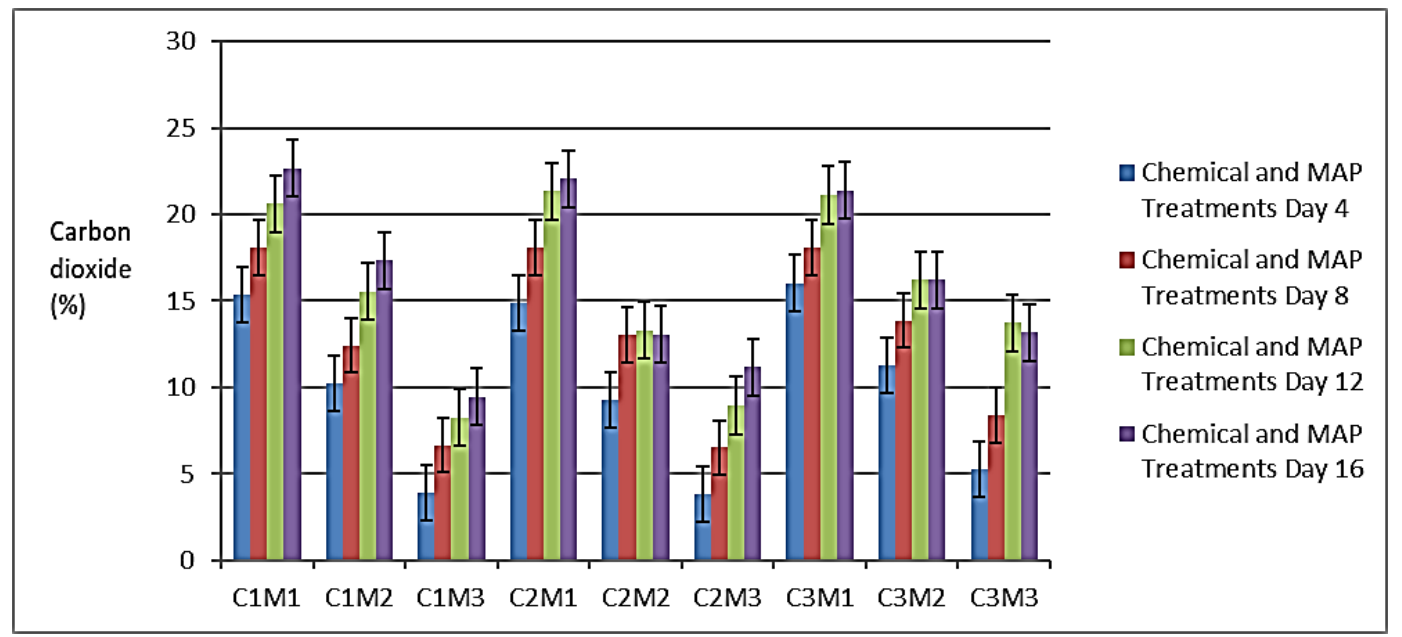

Fig 2: Effect of different chemical and MAP treatments on head space gas composition (percentage carbon dioxide concentration) of button mushroom (Agaricusbisporus) at $8^{\circ} \mathrm{C}$

\section{pH of Agaricus bisporus}

$\mathrm{pH}$ of fresh button mushrooms was recorded as 6.68 and $\mathrm{pH}$ of fresh button mushroom after chemical treatment was recorded as 3.26. Lowering of $\mathrm{pH}$ of button mushrooms after chemical treatment was mainly due to acidic effect of citric acid and calcium chloride. These chemicals might have adsorbed on the surface of chemically treated button mushrooms and had been accumulated in supernatant after centrifugation of ground button mushroom samples. Decreasing trend in $\mathrm{pH}$ of samples was observed with the storage period (Table 1). With the storage time, growth of bacteria was observed and consequent formation of organic acid might have been reason for lowering of $\mathrm{pH}$ (Singh et al., 2018) ${ }^{[27]}$. Sample $\mathrm{C}_{1} \mathrm{M}_{1}$ recorded best results as there was very less decrement in $\mathrm{pH}$ value from initial value. Chemically treated and MAP packed samples showed significantly different results as compared to control samples. Decrement in $\mathrm{pH}$ was recorded in all samples either with low $\mathrm{O}_{2}$ concentration or with high $\mathrm{O}_{2}$ concentration but rate of decrement was comparatively higher in highO ${ }_{2}$ concentration. Higher $\mathrm{O}_{2}$ concentrations trigger aerobic bacteria and other microorganisms to proliferate on the edible food products (Parentelli et al., 2007) ${ }^{[21]}$. In very low $\mathrm{O}_{2}$ concentration anaerobic respiration and proliferation of bacteria like Clostridium botulinum might occur. Lowering of $\mathrm{pH}$ will occur in both the cases as recorded in the investigation and also reported by Jafri et al., $2013^{[9]}$. 


\section{Total soluble solids}

Total soluble solids increases with the storage time indicating higher respiration rates, senescence and ripening (Manurakchinakorn et al., 2010) ${ }^{[19]}$. Chemically treated and MAP packed samples showed better results as compared to control samples (Magaraj et al., 2011) ${ }^{[18]}$. Rate of increment was lesser and more gradual in case of $\mathrm{C}_{1} \mathrm{M}_{1}$ and $\mathrm{C}_{2} \mathrm{M}_{1}$ samples. Total soluble solids after 16 days reached to $6.80 \%$ in case of controlled samples, whereas, TSS for $\mathrm{C}_{1} \mathrm{M}_{1}$ and $\mathrm{C}_{2} \mathrm{M}_{1}$ were recorded as $5.63 \%$ and $5.30 \%$ respectively (Table 1). This investigation clearly shows that rate of senescence were lowest in case of $\mathrm{C}_{2} \mathrm{M}_{1}$ followed by $\mathrm{C}_{1} \mathrm{M}_{1}$ samples (DíazMula et al., 2011) ${ }^{[6]}$.

\section{Relative electrolyte leakage}

Stability of cell membrane permeability was determined by relative electrolyte leakage. Cell membrane permeability to ions increases with storage period which indicate vulnerability of cell membrane to leakage (Tao et al., 2006) ${ }^{[28]}$. There had been significant difference in cell membrane permeability for chemically treated and untreated samples. Samples with $6 \%$ oxygen i.e. $\mathrm{C}_{1} \mathrm{M}_{1}, \mathrm{C}_{2} \mathrm{M}_{1}$ and $\mathrm{C}_{3} \mathrm{M}_{3}$ were detected with little traces of ethanol gas indicating anaerobic respiration in packed samples (Table 1). MAP packed samples recorded less electrolyte leakage as low $\mathrm{O}_{2}$ concentration decreases respiration rates, cap formation, and weight loss. Tyrosinase enzyme activity also gets reduced in low $\mathrm{O}_{2}$ concentration which further prevents enzymatic browning (Li and Zhang, 2013) ${ }^{[15]}$. Chemically untreated and normal air packed sample $\mathrm{C}_{3} \mathrm{M}_{3}$ showed highest electrolyte leakage of about $17.73 \%$.

\section{Weight Loss during Storage}

Button mushrooms are $90 \%$ water so major problem during postharvest is dehydration and rapid loss of moisture from button mushrooms which leads to excessive loss in weight. Dehydration is very common in button mushrooms as they are only covered by very thin layer of epidermal tissue (Singh et $a l ., 2018)^{[27]}$. Transpiration and respiration are the two factors which contribute to weight loss of horticultural products. Transpiration leads to loss of water and respiration leads to loss of dry matter of product (Wei et al., 2017) ${ }^{[29]}$. Weight loss of button mushrooms were significantly affected by both MAP and chemical treatment combinations. Control samples recorded major weight loss after 16 days as compared to chemically treated and MAP packed samples. The main reason for weight loss in control samples was tissue fluid exudation which was accumulated in polyethylene bags. After 16 days, weight loss for $\mathrm{C}_{3} \mathrm{M}_{3}$ samples was recorded as $9.58 \%$, whereas, chemically treated samples showed very less tissue exudation which might be due to insoluble calcium pectate layer in the tissue formed by calcium chloride (Table 1).After 16 days, minimum weight losses for chemically treated and MAP packed samples were recorded as $5.47 \%$ and $6.47 \%$ for $\mathrm{C}_{1} \mathrm{M}_{1}$ and $\mathrm{C}_{2} \mathrm{M}_{1}$ samples respectively. This investigation results demonstrated that different chemical treatments in collaboration with modified atmosphere packaging can effectively reduce moisture losses which contributes to major loss in weight of button mushrooms (Pereda et al., 2011) ${ }^{[22]}$.

Table 1: Effect of different chemical and MAP treatment combinations on physiological attributes of button mushroom (Agaricus bisporus) at $8^{\circ} \mathrm{C}$

\begin{tabular}{|c|c|c|c|c|c|c|c|c|c|c|c|c|c|c|c|c|}
\hline Parameters & \multicolumn{4}{|c|}{ pH } & \multicolumn{4}{|c|}{ Total soluble solids (\%) } & \multicolumn{4}{|c|}{ Relative electrolyte leakage (\%) } & \multicolumn{3}{c|}{ Weight loss (\%) } \\
\hline Days Treatments & $\mathbf{4}$ & $\mathbf{8}$ & $\mathbf{1 2}$ & $\mathbf{1 6}$ & $\mathbf{4}$ & $\mathbf{8}$ & $\mathbf{1 2}$ & $\mathbf{1 6}$ & $\mathbf{4}$ & $\mathbf{8}$ & $\mathbf{1 2}$ & $\mathbf{1 6}$ & $\mathbf{4}$ & $\mathbf{8}$ & $\mathbf{1 2}$ & $\mathbf{1 6}$ \\
\hline $\mathrm{C}_{1} \mathrm{M}_{1}$ & 3.33 & 3.09 & 3.00 & 2.85 & 4.47 & 4.23 & 5.17 & 5.63 & 4.48 & 6.63 & 9.90 & 15.50 & 2.42 & 3.42 & 4.58 & 5.47 \\
\hline $\mathrm{C}_{1} \mathrm{M}_{2}$ & 3.27 & 3.00 & 3.00 & 2.72 & 4.23 & 5.12 & 4.87 & 6.13 & 5.03 & 6.97 & 10.83 & 16.27 & 3.08 & 5.08 & 6.00 & 6.75 \\
\hline $\mathrm{C}_{1} \mathrm{M}_{3}$ & 3.22 & 3.07 & 2.50 & 2.22 & 4.40 & 5.43 & 6.23 & 6.23 & 5.03 & 7.38 & 11.80 & 16.47 & 3.25 & 5.42 & 7.33 & 7.75 \\
\hline $\mathrm{C}_{2} \mathrm{M}_{1}$ & 3.42 & 3.24 & 3.07 & 2.46 & 4.35 & 4.77 & 4.23 & 6.30 & 3.87 & 6.60 & 9.13 & 14.37 & 2.77 & 4.00 & 4.73 & 6.47 \\
\hline $\mathrm{C}_{2} \mathrm{M}_{2}$ & 3.20 & 3.10 & 2.10 & 2.15 & 4.52 & 5.48 & 5.47 & 6.70 & 4.17 & 7.90 & 10.33 & 14.20 & 3.30 & 5.67 & 7.33 & 7.92 \\
\hline $\mathrm{C}_{2} \mathrm{M}_{3}$ & 3.13 & 3.07 & 2.72 & 2.63 & 3.83 & 5.47 & 6.57 & 6.60 & 4.20 & 8.37 & 11.10 & 17.20 & 3.47 & 6.87 & 6.92 & 8.55 \\
\hline $\mathrm{C}_{3} \mathrm{M}_{1}$ & 6.59 & 6.50 & 5.37 & 4.87 & 5.50 & 4.88 & 5.67 & 6.33 & 4.57 & 7.20 & 11.93 & 15.83 & 3.33 & 5.42 & 6.25 & 6.83 \\
\hline $\mathrm{C}_{3} \mathrm{M}_{2}$ & 6.18 & 6.15 & 5.52 & 4.87 & 5.07 & 5.71 & 6.30 & 6.47 & 5.10 & 8.22 & 16.25 & 17.33 & 3.67 & 6.50 & 6.67 & 7.88 \\
\hline $\mathrm{C}_{3} \mathrm{M}_{3}$ & 6.24 & 6.32 & 5.68 & 4.54 & 6.13 & 6.16 & 7.43 & 6.83 & 5.60 & 9.20 & 17.50 & 17.73 & 5.07 & 6.67 & 8.25 & 9.58 \\
\hline $\mathrm{Mean}_{\mathrm{S} . \mathrm{Em} \pm}$ & 4.29 & 4.17 & 3.66 & 3.26 & 4.72 & 5.25 & 5.77 & 6.36 & 4.67 & 7.61 & 12.09 & 16.10 & 3.37 & 5.45 & 6.45 & 7.47 \\
\hline $\mathrm{CD}$ at 5\% & 0.06 & 0.07 & 0.09 & 0.07 & 0.09 & 0.11 & 0.09 & 0.01 & 0.16 & 0.26 & 0.18 & 0.17 & 0.14 & 0.17 & 0.20 & 0.13 \\
\hline $\mathrm{C}$ & 0.18 & 0.21 & 0.26 & 0.20 & 0.27 & 0.31 & 0.25 & 0.28 & 0.47 & 0.70 & 0.52 & 0.48 & 0.41 & 0.48 & 0.58 & 0.36 \\
\hline
\end{tabular}

$\mathrm{C}_{1}: 2.5 \% \mathrm{CaCl}_{2} ; \mathrm{C}_{2}: 2.5 \% \mathrm{CaCl}_{2}, 3 \%$ citric acid, $0.1 \%$ sorbitol; $\mathrm{C}_{3}$ : Blanched at $50^{\circ} \mathrm{C}$

$\mathrm{M}_{1}: 12 \% \mathrm{CO}_{2}, 6 \% \mathrm{O}_{2} ; \mathrm{M}_{2}: 6 \% \mathrm{CO}_{2}, 12 \% \mathrm{O}_{2} ; \mathrm{M}_{3}: 0.04 \% \mathrm{CO}_{2}, 20.95 \% \mathrm{O}_{2}$

\section{Instrumentation colour and Browning index}

Initially luminosity ( $\mathrm{L}^{*}$-values) for fresh button mushroom was recorded as 89.46 which decreases with the storage period. After 16 days, luminosity ( $\mathrm{L}^{*}$-values) ranged from 70.61- 66.58 which were significantly different $(\mathrm{P}<0.05)$ from luminosity after 4 days. L* values denotes lightness index which continuously decreases during storage. MAP packed and chemically treated button mushrooms showed better luminosity (L*-values) as compared to controlled samples. Maximum luminosity (L*-values) were recorded for $\mathrm{C}_{3} \mathrm{M}_{1}$ (70.94) and minimum was recorded for $\mathrm{C}_{3} \mathrm{M}_{3}$ (69.86) after 16 days (Table 2). The red/green(a*-values) increases with storage period and ranged from 1.47- 2.42 after 16 days. The yellow/blue( $b^{*}$-values) also decreases with the storage period and ranged from 11.05-14.73 after 16 days. Decreasing $\mathrm{L}^{*}$ values and increasing $\mathrm{b}^{*}$ values indicates towards non enzymatic browning (Sasnauska et al.,2011) ${ }^{[24]}$. Browning of button mushroom was comparatively lower in case of MAP packed and chemically treated button mushroom $\left(\mathrm{C}_{1} \mathrm{M}_{1}\right.$ and $\mathrm{C}_{2} \mathrm{M}_{1}$ ) as compared to control samples (Kortei et al., 2015) ${ }^{[13]}$. After 16 days maximum and minimum browning index recorded was 26.71 and 18.46 for the sample $C_{3} M_{3}$ and $C_{1} M_{1}$ respectively. 
Table 2: Effect of different chemical and MAP treatment combinations on instrumentation colour and browning index of button mushroom (Agaricus bisporus) at $8^{\circ} \mathrm{C}$.

\begin{tabular}{|c|c|c|c|c|c|c|c|c|c|c|c|c|c|c|c|c|}
\hline Parameters & \multicolumn{4}{|c|}{$\left(\mathbf{L}^{*}\right)$} & \multicolumn{4}{|c|}{$\left(a^{*}\right)$} & \multicolumn{4}{|c|}{ (b*) } & \multicolumn{4}{|c|}{ Browning index } \\
\hline Days Treatments & 4 & 8 & 12 & 16 & 4 & 8 & 12 & 16 & 4 & 8 & 12 & 16 & 4 & 8 & 12 & 16 \\
\hline $\mathrm{C}_{1} \mathrm{M}_{1}$ & 81.36 & 78.77 & 73.62 & 70.61 & 0.91 & 1.00 & 1.41 & 1.89 & 8.78 & 8.99 & 9.50 & 11.05 & 12.30 & 12.64 & 13.79 & 18.46 \\
\hline $\mathrm{C}_{1} \mathrm{M}_{2}$ & 79.37 & 78.50 & 76.60 & 70.57 & 0.93 & 1.04 & 1.47 & 1.68 & 10.18 & 10.75 & 11.71 & 12.25 & 14.18 & 15.37 & 18.08 & 20.04 \\
\hline $\mathrm{C}_{1} \mathrm{M}_{3}$ & 76.27 & 73.91 & 72.72 & 68.90 & 1.04 & 1.24 & 1.38 & 1.58 & 10.68 & 11.54 & 12.42 & 13.22 & 15.82 & 17.80 & 19.69 & 22.54 \\
\hline $\mathrm{C}_{2} \mathrm{M}_{1}$ & 82.29 & 79.11 & 74.91 & 71.24 & 0.62 & 0.72 & 0.98 & 1.47 & 9.40 & 9.98 & 10.34 & 13.40 & 12.63 & 13.90 & 15.65 & 21.90 \\
\hline $\mathrm{C}_{2} \mathrm{M}_{2}$ & 81.07 & 78.80 & 74.91 & 70.48 & 0.87 & 1.03 & 1.29 & 1.47 & 10.02 & 10.36 & 11.86 & 12.75 & 13.32 & 14.77 & 18.22 & 20.61 \\
\hline $\mathrm{C}_{2} \mathrm{M}_{3}$ & 80.00 & 74.91 & 70.24 & 69.24 & 0.96 & 1.12 & 1.28 & 1.57 & 10.42 & 11.39 & 8.62 & 13.33 & 14.70 & 17.20 & 20.14 & 22.59 \\
\hline $\mathrm{C}_{3} \mathrm{M}_{1}$ & 79.61 & 77.24 & 73.28 & 70.94 & 1.21 & 1.34 & 1.69 & 1.73 & 10.90 & 12.00 & 12.97 & 14.73 & 15.50 & 17.54 & 21.04 & 23.12 \\
\hline $\mathrm{C}_{3} \mathrm{M}_{2}$ & 78.31 & 76.58 & 73.65 & 70.11 & 1.26 & 1.21 & 1.54 & 1.94 & 11.73 & 11.60 & 12.90 & 14.42 & 17.11 & 16.78 & 20.38 & 23.62 \\
\hline $\mathrm{C}_{3} \mathrm{M}_{3}$ & 78.39 & 73.91 & 69.94 & 66.58 & 1.14 & 1.77 & 2.03 & 2.42 & 10.47 & 12.07 & 12.85 & 14.48 & 16.08 & 19.35 & 21.74 & 26.71 \\
\hline Mean & 79.63 & 76.86 & 73.32 & 69.85 & 0.99 & 1.16 & 1.45 & 1.75 & 10.29 & 10.96 & 11.46 & 13.29 & 14.62 & 16.15 & 18.75 & 22.18 \\
\hline S.Em \pm & 0.25 & 1.70 & 1.15 & 1.40 & 0.07 & 0.12 & 0.11 & 0.08 & 0.15 & 0.24 & 0.48 & 0.16 & 0.32 & 0.33 & 0.34 & 0.40 \\
\hline $\mathrm{CD}$ at $5 \%$ & 0.72 & 4.78 & 3.23 & 3.92 & 0.21 & 0.28 & 0.39 & 0.24 & 0.42 & 0.68 & 1.35 & 0.45 & 0.90 & 0.93 & 0.97 & 1.14 \\
\hline
\end{tabular}

\section{Conclusion}

The present investigation suggested that there is quality enhancement of button mushroom by combined effect of both chemical and MAP treatment. MAP packed button mushroom samples depicted higher membrane stability and noticed very less weight loss during storage as compared to controlled samples. Browning of chemically treated MAP packed button mushroom samples was significantly lower as compared to controlled samples. MAP composition with $12 \% \mathrm{CO}_{2} ; 6 \% \mathrm{O}_{2}$ gas composition were best suited for maintaining post-harvest quality of button mushroom with low respiratory rates, low leakage of electrolyte, better sensory and colour parameters. Combined effect of integrated MAP and chemical treatments serves as effective approach for delaying senescence of button mushroom during post-harvest storage.

\section{References}

1. Anantheswaran RC, Sunkara R. Use of commercial moisture absorbers to increase the shelf life of fresh mushrooms, In: Royse (eds.), Mushroom Biology and Mushroom Products, 1996, 563-568.

2. Antmann G, Ares G, Lema P, Lareo C. Influence of modified atmosphere packaging on sensory quality of shiitake mushrooms. Postharvest Biology and Technology. 2008; 49:164-170.

3. Ares G, Parentelli C, Gámbaro A, Lareo C, Lema P. Sensory shelf life of shiitake mushrooms stored under passive modified atmosphere. Postharvest Biology and Technology. 2006; 41:191-197.

4. Belay ZA, Caleb OJ, Opara UL. Modelling approaches for designing and evaluating the performance of modified atmosphere packaging (MAP) systems for fresh produce: A review. Food Packaging and Shelf Life. 2016; 10:1-15.

5. Brennan M, LePort G, Gormley R. Post-harvest treatment with citric acid or hydrogen peroxide to extend the shelf life of fresh sliced mushrooms. Food Science and Technology. 2000; 33:285-289.

6. Díaz-Mula HM, Martínez-Romero D, Castillo S, Serrano, M, Valero, D. Modified atmosphere packaging of yellow and purple plum cultivars. Postharvest Biology and Technology. 2011; 61:103-109.

7. Eissa HAA. Effect of chitosan coating on shelf-life and quality of fresh-cut mushroom. Polish Journal of Food and Nutrition Sciences. 2008; 58:95-105.

8. Hunter Lab Technical Manual, CIE L*a*b* colorscale. Applications Note- Insight on Color, Hunter Lab, International Atomic Energy Agency (IAEA), 1992. TECDOC-639, Vienna. 2008; 8(7):1-4.
9. Jafri A, Jha A, Bunkar DS, Ram RC. Quality retention of oyster mushrooms (Pleurotus florida) by a combination of chemical treatments and modified atmosphere packaging. Postharvest Biology and Technology. 2013; 76:112-118.

10. Kaya C, Kirnak H, Higgs D, Saltali K. Supplementary calcium enhances plant growth and fruit yield in strawberry cultivars grown at high $(\mathrm{NaCl})$ salinity. Scientia Horticulture. 2002; 93:65-74.

11. Khan ZA, Aisikaer G, Khan RU, Bu J, Jiang Z, Ni Z et al. Effects of composite chemical pretreatment on maintaining quality in button mushrooms (Agaricus bisporus) during postharvest storage. Postharvest Biology and Technology. 2014; 95:36-41.

12. Kortei NK, Odamtten GT, Obodai M, Appiah V, Abbey $\mathrm{L}$, Yeboah $\mathrm{CO}$ et al. Influence of gamma radiation on some textural properties of fresh and dried oyster mushrooms (Pleurotus ostreatus). Annals Food Science and Technology. 2015; 16(1):165-175.

13. Kortei NK, Odamtten GT, Obodai M, Appiah V, Akonor PT. Determination of color parameters of gamma irradiated fresh and dried mushrooms during storage. Croatian Journal of Food Technology. Biotechnology and Nutrition. 2015; 10(1-2):66-71.

14. Licciardello F, Kharchoufi S, Muratore G, Restuccia C. Effect of edible coating combined with pomegranate peel extract on the quality maintenance of white shrimps (Parapenaeus longirostris) during refrigerated storage. Food Packaging and Shelf Life. 2018; 17:114-119.

15. Li M, Zhang M. The Physiological and Quality Change of Mushroom Agaricus bisporus Stored in Modified Atmosphere Packaging with Various Sizes of Silicone Gum Film Window. Food Science and Technoogy Research. 2013; 19(4):569-576.

16. Li Y, Ishikawa Y. Effect of active modified atmosphere packaging with different initial gas compositions on nutritional compounds of shiitake mushrooms (Lentinus edodes). Postharvest Biology and Technology. 2014; 92:107-113.

17. Lopez-Malo A, Palou E, Barbosa-Canovas GV, WeltiChanes J, Swanson BG. Polyphenol oxidase activity and color changes during storage of high hydrostatic pressure treated avocado puree. Food Research International. 1998; 31(8):549-556.

18. Magaraj S, Sadawarti MJ, Prasad S. Assessment of quality of pears stored in laminated modified atmosphere packages. International Journal of Food Properties. 2011; 14:1110-1123. 
19. Manurakchinakorn S, Intavong $P$, Yuennan $P$, Tonwattana S, Pankong A. Effect of storage conditions on quality attributes of fresh-cut mango steen. In: ISHS Acta Horticulturae 857: IX International Controlled Atmosphere Research Conference, 2010.

20. Mohammadi A, Shahin R, Zahra ED, Alirez K. Kinetic models for colour changes in kiwi fruit slices during hot air drying. World Journal of Agricultural Sciences. 2008; 4(3):376-383.

21. Parentelli C, Ares G, Corona M, Lareo C, Gámbaro A, Soubes M. Sensory and microbiological quality of shiitake mushrooms in modified-atmosphere packages. Journal of the Science of Food and Agriculture. 2007; 87:1645-1652.

22. Pereda M, Ponce AG, Marcovich NE, Ruseckaite RA, Martucci JF. Chitosan-gelatin composites and bi-layer films with potential antimicrobial activity. Food Hydrocolloids. 2011; 25(5):1372-1381.

23. Roy S, Anantheswaran RC, Beelman RB. Sorbitol increases shelf life of fresh mushrooms stored in conventional packages. Journal of Food Science. 1995; 60:1254-1259.

24. Sasnauskas A, Viskelis P, Rubinskiene M, Bobinas C, Kvikliene N. Changes in apple fruit quality during a modified atmosphere storage. Journal of Fruit and Ornamental Plant Research. 2011; 19(1):155-165.

25. Schnell RJ, Silva AD, Meerow AW, Winterstein M, Cervantes C, Brown JS. Determination of color and fruit traits of half-sib families of mango (Magnifera indica L.). Proceedings of the Florida State Horticultural Society. 2005; 118:253-257.

26. Singh N, Vaidya D, Mishra V, Thakur KS. Shelf life and storage quality of white button mushrooms (Agaricus bisporus) as affected by packaging material. International Journal of Agricultural Research. 2016; 4(11):1790-1799.

27. Singh S, Gaikwad KK, Lee M, Lee YS. Thermally buffered corrugated packaging for preserving the postharvest freshness of mushrooms (Agaricus bispours). Journal of Food Engineering. 2018; 216:11-19.

28. Tao F, Zhang M, Yu HQ, Sun JC. Effects of different storage conditions on chemical and physical properties of white mushrooms after vacuum cooling. Journal of Food Engineering. 2006; 77:545-549.

29. Wei W, Lv P, Xia Q, Tan F, Sun F, Yu W. Fresh-keeping effects of three types of modified atmosphere packaging of pine-mushrooms. Postharvest Biology and Technology. 2017; 132:62-70. 